\title{
Apigenin inhibits osteoblastogenesis and osteoclastogenesis and prevents bone loss in ovariectomized mice
}

\author{
Tadashi Goto $\cdot$ Keitaro Hagiwara • \\ Nobuaki Shirai · Kaoru Yoshida • \\ Hiromi Hagiwara
}

Received: 10 September 2013/Accepted: 23 January 2014/Published online: 6 February 2014

(C) The Author(s) 2014. This article is published with open access at Springerlink.com

\begin{abstract}
Polyphenol have been reported to have physiological effects with respect to alleviating diseases such as osteoporosis and osteopetrosis. We recently reported that the olive polyphenol hydroxytyrosol accelerates bone formation both in vivo and in vitro. The present study was designed to evaluate the in vivo and in vitro effects of apigenin (4',5,7-trihydroxyflavone), one of the major polyphenols in olives and parsley, on bone formation by using cultured osteoblasts and osteoclasts and ovariectomized (OVX) mice, respectively. Apigenin markedly inhibited cell proliferation and indices of osteoblast differentiation, such as collagen production, alkaline phosphatase activity, and calcium deposition in osteoblastic MC3T3-E1 cells at concentrations of $1-10 \mu \mathrm{M}$. At $10 \mu \mathrm{M}$, apigenin
\end{abstract}

Tadashi Goto and Keitaro Hagiwara have corresponded equally to this work.

T. Goto $\cdot$ N. Shirai $\cdot$ H. Hagiwara $(\bowtie)$

Department of Biomedical Engineering, Toin University

of Yokohama, 1614 Kurogane-cho, Aoba-ku,

Yokohama 225-8503, Japan

e-mail: hagiwara@cc.toin.ac.jp

K. Hagiwara

Department of Biological Sciences, Tokyo Institute of

Technology, 4259 Nagatsuta-cho, Midori-ku, Yokohama

226-8501, Japan

K. Hagiwara

Division of Molecular and Cellular Medicine, National

Cancer Center Research Institute, 5-1-1, Tsukiji, Chuo-ku,

Tokyo 104-0045, Japan completely inhibited the formation of multinucleated osteoclasts from mouse splenic cells. Moreover, injection of apigenin at $10 \mathrm{mg} \mathrm{kg}^{-1}$ body weight significantly suppressed trabecular bone loss in the femurs of OVX mice. Our findings indicate that apigenin may have critical effects on bone maintenance in vivo.

Keywords Apigenin - Polyphenol - Osteoblast ·

Osteoclast · Ovariectomized mice $\cdot$ Bone loss

\section{Introduction}

In bone tissues, both the formation and maintenance of bone are controlled by bone-forming osteoblasts and bone-resorbing osteoclasts, and an imbalance between these two cell types leads to bone metabolic diseases

\author{
N. Shirai \\ Tsukuba Laboratories, Nemoto Science Co. Ltd, 6136-4 \\ Ohnogoh-machi, Joso-shi, Ibaraki 300-2521, Japan \\ K. Yoshida \\ Biomedical Engineering Center, Toin University of \\ Yokohama, 1614 Kurogane-cho, Aoba-ku, \\ Yokohama 225-8503, Japan
}


<smiles>O=c1cc(-c2ccc(O)cc2)oc2cc(O)cc(O)c12</smiles>

Fig. 1 Structure of apigenin

such as osteoporosis and osteopetrosis (Riggs 1987). Bone formation involves a complex series of events that include the proliferation and differentiation of osteoprogenitor cells, resulting in the formation of a mineralized extracellular matrix. The deposition of calcium and the sequential expression of type I collagen, alkaline phosphatase, and osteocalcin are known as markers of osteoblastic differentiation. Several model systems have been developed for studying the proliferation and differentiation of bone-forming cells in vitro and the molecular biology of the mineralization process, such as preosteoblastic cells from mouse calvariae (MC3T3-E1 cells) and osteoblast-like cells from rat calvariae (Bredford et al. 1993; Hagiwara et al. 1996; Liu et al. 1994; Stein et al. 1990). Osteoclasts are multinucleated giant cells with the ability to resorb mineralized tissues. They are formed from hematopoietic cells of the monocyte/macrophage lineage (Udagawa et al. 1990). The development of osteoclasts in culture is strictly dependent on support provided by osteoblasts and/or stromal cells (Udagawa et al. 1990). The formation and activation of osteoclasts are controlled by the combined actions of receptor activator of nuclear factor- $\kappa \mathrm{B}$ ligand (RANKL) and macrophage colony-stimulating factor (M-CSF). Here, we used a single culture of mouse spleen cells with added M-CSF and soluble RANKL (Notoya et al. 2007).

Apigenin (4',5,7-trihydroxyflavone), a member of the flavone family of flavonoid compounds (Fig. 1), is widely distributed in many vegetables and fruits including olives, parsley, and apples. This compound has antitumor and antioxidant properties (Patel et al. 2007; Shukla and Gupta 2010). In addition, apigenin has been found to have significant effects on inhibiting growth, arresting the cell cycle, and inducing apoptosis in many cancers and leukemia (Budhraja et al. 2012; Shukla and Gupta 2007; Zhu et al. 2013). Apigenin is also known to be a strong inhibitor of ornithine decarboxylase activity (Wei et al. 1990),
LPS-induced cyclooxygenase- 2 and nitric oxide synthase-2 activity (Liang et al. 1999), and protein kinase C activity (Lee and Lin 1997). A few studies have reported that apigenin inhibits osteoclastogenesis and osteoclast function (Bandyopadhyay et al. 2006). However, little information is available on the effects of apigenin on bone metabolism.

The present study was designed to evaluate the in vivo and in vitro effects of apigenin on the formation and maintenance of bone by using mice and cultured mouse cells, respectively. We also investigated preventive effects of apigenin on bone loss in adult mice with ovariectomy-induced osteoporosis. Our results indicate that apigenin may be useful in the prevention and treatment of osteoporosis.

\section{Materials and methods}

\section{Materials}

Apigenin was purchased from Enzo Life Science (Plymouth, PA, USA). $\alpha$-Modified minimum essential medium ( $\alpha$-MEM), RPMI 1640 medium, and penicillin/streptomycin antibiotic mixture were obtained from Life Technologies, Inc. (Grand Island, NY, USA). Fetal bovine serum was obtained from Moregate BioTech (Bulimba, Australia). Recombinant murine M-CSF and recombinant human soluble RANKL (sRANKL) were from R\&D Systems (Minneapolis, MN, USA) and Pepro Tech EC., Ltd. (London, UK), respectively.

Osteoblastic cell cultures

Preosteoblastic MC3T3-E1 cells were obtained from RIKEN Cell Bank (Tsukuba, Japan). Cells were maintained in a $55-\mathrm{cm}^{2}$ dish in $\alpha$-MEM, supplemented with $10 \%$ fetal bovine serum, 50 units $\mathrm{mL}^{-1}$ penicillin and $50 \mu \mathrm{g} \mathrm{mL}^{-1}$ streptomycin, in a humidified atmosphere of $5 \% \mathrm{CO}_{2}$ in air at $37{ }^{\circ} \mathrm{C}$. After reaching $70 \%$ confluence, cells were detached by treatment with $0.05 \%$ trypsin, replated in either $55-\mathrm{cm}^{2}$ dishes or 12-well plates (area of each well, $3.8 \mathrm{~cm}^{2}$ ) at a density of $1 \times 10^{4}$ cells $\mathrm{cm}^{-2}$, and grown in $\alpha$-MEM supplemented with $10 \%$ fetal bovine serum, 50 units $\mathrm{mL}^{-1}$ penicillin, $50 \mu \mathrm{g} \mathrm{mL}^{-1}$ streptomycin, $5 \mathrm{mM} \beta$-glycerophosphate (Sigma-Aldrich, Tokyo, Japan), and $50 \mu \mathrm{g} \mathrm{mL}^{-1}$ ascorbic acid (Sigma-Aldrich). Fresh medium and apigenin were supplied to cells at 2-day 
intervals. Apigenin at 1,5 , and $10 \mu \mathrm{M}$ was added to medium according to previous study (Bandyopadhyay et al. 2006). MC3T3-E1 cells formed nodules, and mineralization of nodules was observed after cultivation for 2-3 weeks.

Formation of osteoclastic cells

Multinucleated osteoclastic cells formed from spleen cells by adding osteoclast differentiating factors, RANKL and M-CSF. Spleen cells were collected from the splenic tissues of 6-week-old male ddY mice (Sankyo Laboservice, Tokyo, Japan). Erythrocytes contaminating the spleen cell fraction were eliminated by adding $0.83 \%$ ammonium chloride in $10 \mathrm{mM}$ Tris$\mathrm{HCl}(\mathrm{pH} \mathrm{7.4)}$ to the cell pellet. Mouse spleen cells $\left(2.4 \times 10^{5}\right.$ cells/well $)$ in 96 -well plates $\left(0.32 \mathrm{~cm}^{2} /\right.$ well) were cultured with $50 \mathrm{ng} \mathrm{mL}^{-1}$ human sRANKL and $30 \mathrm{ng} \mathrm{mL}{ }^{-1} \mathrm{M}$-CSF for 7 days. Cultures were maintained at $37{ }^{\circ} \mathrm{C}$ in a humidified atmosphere of $5 \%$ $\mathrm{CO}_{2}$ in air. Fresh medium and apigenin at 1, 5, $10 \mu \mathrm{M}$ were supplied at 2-day intervals. Multinucleated osteoclastic cells formed were fixed on the well in $3.7 \%$ formaldehyde for $5 \mathrm{~min}$ and then in a mixture of ethanol and acetone (1:1; v:v) for $1 \mathrm{~min}$. These were then stained for tartrate resistant acid phosphatase (TRAP) activity, one of osteoclastic differentiate markers. TRAP-positive multinucleated cells (five or more nuclei) were counted under a microscope (IX70; Olympus, Tokyo, Japan).

The Institutional Animal Care and Use Committee of Toin University of Yokohama approved all animal protocols and procedures.

Toxicity of apigenin for cells

MC3T3-E1 cells were replated in 96-well plates (area of each well, $0.32 \mathrm{~cm}^{2}$ ) at a density of $1 \times 10^{3}$ cells $\mathrm{cm}^{-2}$ and grown in $\alpha$-MEM supplemented with $10 \%$ fetal bovine serum, 50 units $\mathrm{mL}^{-1}$ penicillin, $50 \mu \mathrm{g} \mathrm{mL}^{-1}$ streptomycin, and apigenin at various concentrations. After subculture for 53 or $74 \mathrm{~h}$, the cell layers were washed with RPMI 1640 medium. 3-[4,5-Dimethylthiazol-2-yl]-2,5-diphenyltetrazolium bromide (MTT; DOJINDO, Kumamoto, Japan) reagent $\left(0.5 \mathrm{mg} \mathrm{mL}^{-1}\right.$ RPMI 1640) was added to each well, followed by incubation for $4 \mathrm{~h}$ for formazan formation. After the medium was removed, dimethyl sulfoxide was added to each well to dissolve the formazan, and absorbance was measured at $570 \mathrm{~nm}$. The absorbance of the solution at $570 \mathrm{~nm}$ was related to the number of live cells.

Sirius Red staining of collagen

Collagen was stained with Sirius Red (TullbergReinert and Jundt, 1999). Sirius Red F3BA was purchased from Polysciences, Inc. (Wamington, PA, USA). Dye was dissolved in saturated aqueous picric acid at a concentration of $100 \mathrm{mg} \mathrm{dL}^{-1}$. Cells were plated in 24-well plates $\left(2.0 \mathrm{~cm}^{2} /\right.$ well $)$ at a density of $1 \times 10^{4}$ cells $\mathrm{cm}^{-2}$ and subcultured with apigenin for 3 days. Cell layers were air-dried overnight on a sterile bench and fixed with $1 \mathrm{~mL}$ of Bouin's solution (Sigma, St. Louis, MO, USA) for $1 \mathrm{~h}$. Fixation fluid was removed by suction and culture plates were washed by immersion in running tap water for $15 \mathrm{~min}$. Culture plates were air-dried, and $1 \mathrm{~mL}$ of Sirius Red dye reagent was added. Cells were stained for $1 \mathrm{~h}$ with shaking on a plate shaker. Stained cell layers were washed with $0.01 \mathrm{~N}$ hydrochloric acid to remove all non-bound dye, and stained material was dissolved in $0.5 \mathrm{~mL}$ of $0.1 \mathrm{~N}$ sodium hydroxide by using a plate shaker for $30 \mathrm{~min}$ at room temperature, after which the absorbance was measured at $550 \mathrm{~nm}$.

Measurement of alkaline phosphatase activity

MC3T3-E1 cells were subcultured in 12-well plates (3.8 $\mathrm{cm}^{2} /$ well) in $\alpha$-MEM containing $10 \%$ fetal bovine serum, $5 \mathrm{mM} \beta$-glycerophosphate, and $50 \mu \mathrm{g} \mathrm{mL}^{-1}$ ascorbic acid. After the cells had reached confluence (day 3), apigenin was added to cultures at various concentrations for 12 days. Cells were washed with $10 \mathrm{mM}$ Tris- $\mathrm{HCl}, \mathrm{pH} 7.2$, and were sonicated in $1 \mathrm{~mL}$ of $50 \mathrm{mM}$ Tris- $\mathrm{HCl}(\mathrm{pH}$ 7.2) containing $0.1 \%$ Triton $\mathrm{X}-100$ and $2 \mathrm{mM} \mathrm{MgCl} 2$ for $15 \mathrm{~s}$ with a sonicator (Ultrasonic Disruptor UD-201; Tomy Co., Tokyo, Japan). Alkaline phosphatase activity was determined using an established technique with $p$-nitrophenyl phosphate as the substrate (Hagiwara et al. 2011). Protein concentrations were determined using BCA protein assay reagent (Pierce Chemical Co., Rockford, IL, USA) with bovine serum albumin as a standard.

Quantitation of calcium deposition

MC3T3-E1 cells were subcultured in $\alpha$-MEM containing $10 \%$ fetal bovine serum, $5 \mathrm{mM} \beta$-glycerophosphate, 
and $50 \mu \mathrm{g} \mathrm{mL}^{-1}$ ascorbic acid. After the cells had reached confluence (day 3), apigenin was added at various concentrations to the culture medium and cells were subcultured for 15 days. The amount of calcium, deposited as hydroxyapatite in the cell layer, was measured as follows: Layers of cells in 12-well plates $\left(3.8 \mathrm{~cm}^{2} /\right.$ well $)$ were washed with PBS and incubated overnight with $1 \mathrm{~mL}$ of $2 \mathrm{~N} \mathrm{HCl}$ with gentle shaking. $\mathrm{Ca}^{2+}$ ions in the samples were quantitated by the $o$ cresolphthalein complexone method with a Calcium $\mathrm{C}$ kit (Wako Pure Chemical Industries, Osaka, Japan). This kit is specific for $\mathrm{Ca}^{2+}$ ions and has a detection limit of $1 \mu \mathrm{g} \mathrm{mL}^{-1}$. The solution of $\mathrm{Ca}^{2+}$ ions $\left(20 \mathrm{mg} \mathrm{dL}^{-1}\right)$ provided in the kit was used as the standard solution.

Analysis of bone mineral density of OVX mice treated with apigenin

BALB/c female mice (6-weeks old) were purchased from Sankyo Laboservice (Tokyo, Japan) and were housed individually at $24{ }^{\circ} \mathrm{C}$ with a $12 \mathrm{~h}$ light-dark cycle. The mice underwent a sham-operation $(n=5)$ or were surgically ovariectomized (OVX; $n=10)$ under anesthesia with $\mathrm{Nembutal}^{\circledR}$ injection (Dainippon Sumitomo Pharma, Tokyo, Japan). The mice were assigned to three groups ( $\mathrm{n}=5$ for each): (1) untreated (Sham: sham-operated controls); (2) untreated (OVX controls); and (3) OVX administered intraperitoneally with apigenin (10 $\mathrm{mg} \mathrm{kg}^{-1}$ body weight) at 2-day intervals. Apigenin was dissolved in ethanol and was diluted tenfold with saline before injection. The volume ingested was $50 \mu \mathrm{L}$. After the 28-day experimental period, the left and right femurs were surgically obtained from the anesthetized mice. The success of ovariectomy was confirmed by uterine atrophy in OVX mice.

The bone mineral density of the femurs was assessed using an X-ray CT System (LA Theata LCT-100; Aloka, Tokyo, Japan). We monitored the bone mineral density of femurs at $0.3 \mathrm{~mm}$ intervals and separately analyzed each trabecular and cortical bone. Values at 2.1 and $2.4 \mathrm{~mm}$ from the epiphysis of the femur are shown in the figures. Animal protocols and procedures were approved by the Institutional Animal Care and Use Committee of the Toin University of Yokohama.

Statistical analysis

Numerical data have been expressed as mean \pm SD values of the results from three to four cultures, and the

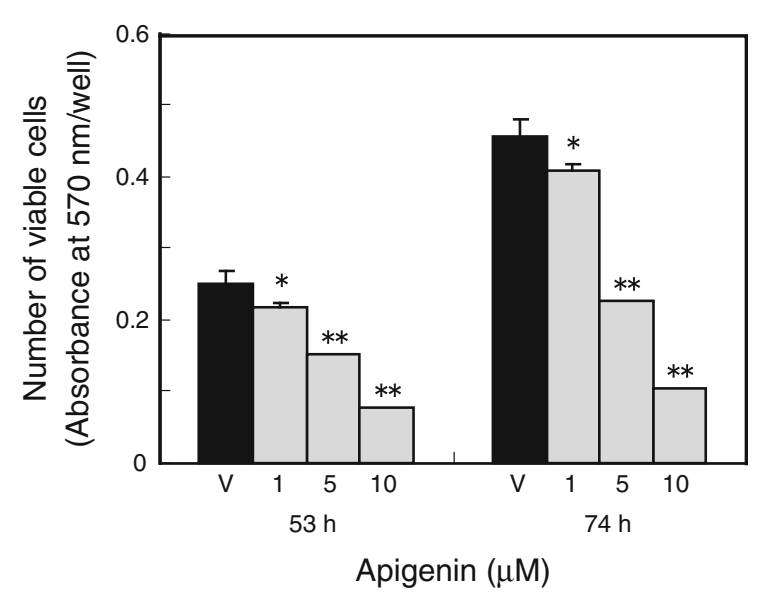

Fig. 2 Effects of apigenin on osteoblastic cell viability. MC3T3E1 cells $\left(1 \times 10^{3}\right.$ cells/well; 96-well plates $)$ were exposed to the olive polyphenol apigenin at various concentrations $(1-10 \mu \mathrm{M})$ and were subcultured for 53 or $74 \mathrm{~h}$. After treatment with apigenin, the cells were treated with MTT (50 $\mu \mathrm{g} /$ well) for $4 \mathrm{~h}$, and the absorbance at $570 \mathrm{~nm}$ was measured. The values represent the mean \pm SD of results from three wells. Data are representative of results from three separate experiments. $* P<0.05$ versus vehicle $(\mathrm{V})$ and $* * P<0.01$ versus vehicle $(\mathrm{V})$

significance of differences was analyzed by ANOVA (Dunnett's test). Statistical significance was set at $P<$ 0.05. Experiments were repeated independently in triplicate and the results were qualitatively identical in every case. Results from representative experiments are shown.

\section{Results}

Effects of apigenin on cultured osteoblasts

We first evaluated the toxicity of apigenin for MC3T3-E1 cells by using the MTT assay. Apigenin decreased in the number of viable MC3T3-E1 cells in a dose-dependent manner (Fig. 2). Exposure of MC3T3-E1 cells to $10 \mu \mathrm{M}$ apigenin decreased in viable cell number by approximately 70 and $77 \%$ at 53 and $74 \mathrm{~h}$, respectively, relative to control cultures treated with the vehicle alone. However, exposure of MC3T3-E1 cells to apigenin at $10 \mu \mathrm{M}$ did not affect cell morphological features.

To assess the effects of apigenin on the differentiation and mineralization of MC3T3-E1 cells, we added apigenin to the culture medium of post-proliferative cells and assayed collagen production, alkaline phosphatase activity, and calcium deposition (Fig. 3). Collagen is 
Fig. 3 Effects of apigenin on collagen production, alkaline phosphatase activity, and mineralization of osteoblasts. MC3T3E1 cells were cultured in 12-well plates $\left(3.8 \mathrm{~cm}^{2} /\right.$ well) or 24-well plates $\left(2.0 \mathrm{~cm}^{2} /\right.$ well) with $\alpha$-MEM containing $10 \%$ fetal bovine serum, $5 \mathrm{mM} \beta$-glycerophosphate, and $50 \mu \mathrm{g} \mathrm{mL}^{-1}$ ascorbic acid. After the cells reached confluence (day 3), the olive polyphenol apigenin was added at various concentrations $(1-10 \mu \mathrm{M})$ to the culture medium. Fresh medium with test compound was supplied at 3-day intervals. a Collagen production was measured at day 7 as described in the method. Cell layers in 24 -well plates $\left(2.0 \mathrm{~cm}^{2} /\right.$ well $)$ were fixed with Bouin's solution and stained with Sirius Red dye reagent. Stained material was dissolved in $0.1 \mathrm{~N}$ sodium hydroxide and the absorbance was measured at $550 \mathrm{~nm}$. b Alkaline phosphatase activity was measured at day 14 as described in the method. $\mathbf{c}$ Deposition of $\mathrm{Ca}^{2+}$ ions was measured at days 21 and 24. Quantitative analysis of $\mathrm{Ca}^{2+}$ ions was performed as described in the method. All values represent the mean $\pm \mathrm{SD}$ of the results from three wells. Data are representative of results from three separate experiments. $* P<0.05$ versus vehicle $(\mathrm{V})$ and $* * P<0.01$ versus vehicle $(\mathrm{V})$

an early stage marker of osteoblastic differentiation, and as shown in Fig. 3a, incubation of cells with $10 \mu \mathrm{M}$ apigenin for 7 days significantly inhibited the production of collagen. We then examined the activity of alkaline phosphatase, a middle-stage marker of osteoblastic differentiation, in osteoblastic cells. Apigenin significantly decreased the activity of alkaline phosphatase in MC3T3-E1 cells on day 14 when used at $10 \mu \mathrm{M}$ (Fig. 3b). Furthermore, as demonstrated in Fig. 3c, apigenin dose-dependently inhibited calcium deposition by MC3T3-E1 cells on days 21 and 24. Exposure of MC3T3-E1 cells to $10 \mu \mathrm{M}$ apigenin decreased calcium deposition by approximately 43 and $45 \%$ on days 21 and 24 , respectively, relative to control cultures treated with the vehicle alone (Fig. 3c).

Effects of apigenin on the formation of multinucleated osteoclasts

Multinucleated osteoclastic cells were formed from mouse splenic cells by the addition of $30 \mathrm{ng} \mathrm{mL}^{-1}$ $\mathrm{M}-\mathrm{CSF}$ and $50 \mathrm{ng} \mathrm{mL}^{-1}$ human recombinant sRANKL. Figure 4a shows representative results for the detection of TRAP activity in multinucleated osteoclastic cells treated with apigenin at the indicated concentrations in the figure. Formation of TRAP-positive multinucleated osteoclastic cells was dose-dependently inhibited by the addition of apigenin (Fig. 4b). Exposure of splenic cells to $10 \mu \mathrm{M}$ apigenin completely inhibited the formation of multinucleated osteoclastic cells relative to control cultures treated with the vehicle alone.
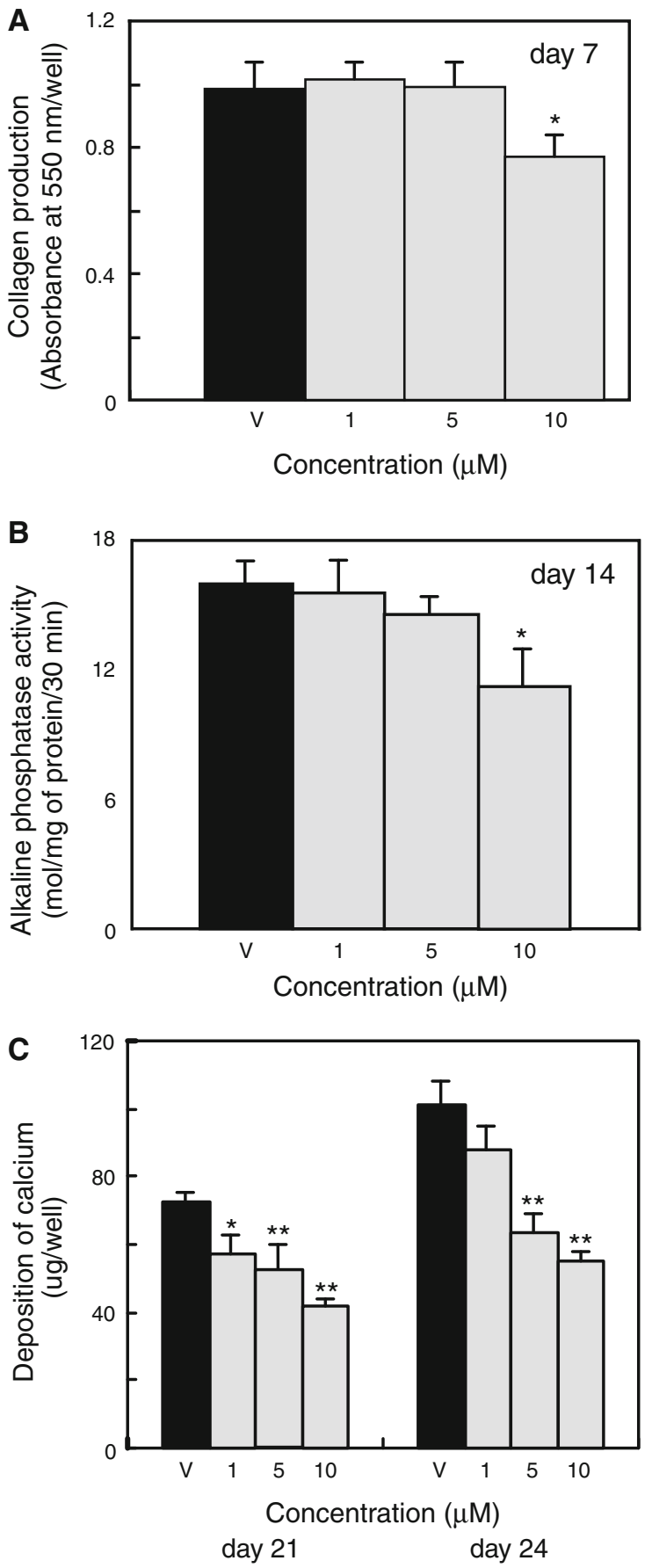

Effects of polyphenols on bone loss in OVX mice

We examined the effects of apigenin on bone mineral density by using OVX mice. We used a polyphenol dose of $10 \mathrm{mg} \mathrm{kg}^{-1}$ body weight because this concentration of polyphenol has been reported to be 
A

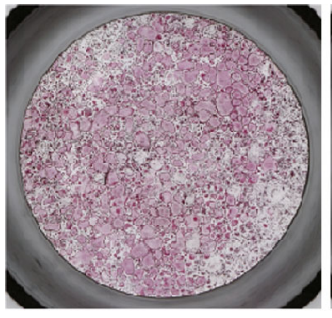

Vehicle

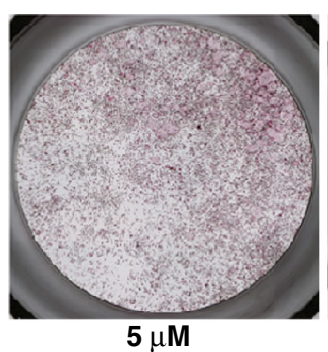

$5 \mu \mathrm{M}$

\section{B}

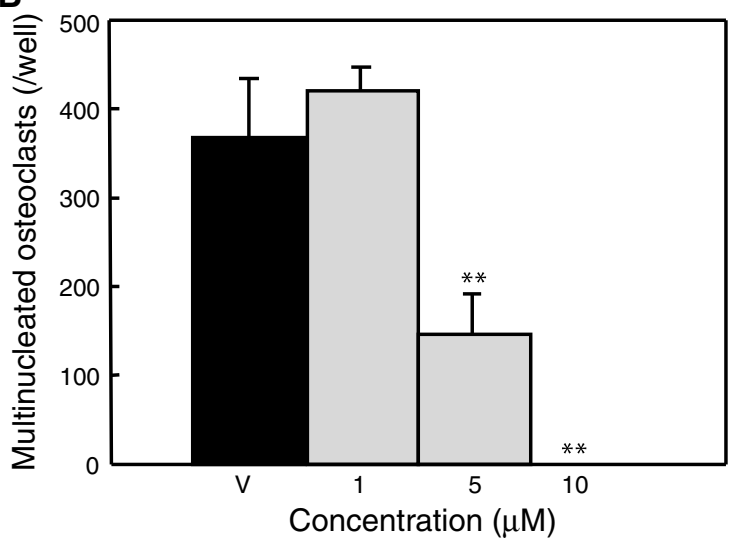

Fig. 4 Effects of apigenin on osteoclast formation. Osteoclasts were formed from mouse spleen cells. a Typical results of staining for the detection of TRAP activity. Apigenin was added to cultures at the indicated concentrations. Cultured cells were then stained for TRAP activity on day 7. b Apigenin was added to cultures at the indicated concentrations. Cultured cells were then stained for TRAP activity on day 7. TRAP-positive multinucleated cells (five or more nuclei) were counted under a microscope. Columns and bars show mean \pm SD values of the results from five wells. Data are representative of the results of three separate experiments. ${ }^{*} P<0.01$ versus vehicle $(\mathrm{V})$

effective in vivo in previous studies (Hagiwara et al. 2011; Notoya et al. 2006). Compared with the values for the Sham group $(18.8 \pm 1.9 \mathrm{~g})$, the final body weights in the OVX group $(20.8 \pm 0.8 \mathrm{~g})$ were significantly increased at 28 days after the operation. There were no differences in body weight between the
OVX group (20.8 $\pm 0.8 \mathrm{~g})$ and the OVX-administered apigenin group $(21.0 \pm 1.3 \mathrm{~g})$ at 28 days after the operation. Ovariectomy induced a severe decrease in the bone mineral density of the trabecular bone of mice (Fig. 5). At 2.1 and $2.4 \mathrm{~mm}$ from the epiphysis of the femur, the bone mineral density in the OVX group was significantly lower than that in the Sham group (65 and $67 \%$, respectively). Administration of apigenin at $10 \mathrm{mg} \mathrm{kg}^{-1}$ body weight significantly reduced the loss of trabecular bone in OVX mice (Fig. 5). At 2.1 and $2.4 \mathrm{~mm}$ from the epiphysis of the femur, significant recovery ( 83 and $91 \%$, respectively) of bone mineral density was observed in the OVX-administered apigenin group compared to that in the OVX group. In contrast, apigenin did not affect the loss of cortical bone mineral density in OVX mice.

\section{Discussion}

We screened natural polyphenols for the ability to regulate the proliferation, differentiation, and function of cultured osteoblasts and osteoclasts in order to identify factors that may cause, prevent, or treat bone metabolic diseases such as osteoporosis and osteopetrosis. We had previously reported that the isoflavone genistein attenuates osteoclastogenesis by decreasing the levels of receptor activator NF- $\kappa \mathrm{B}$ ligand mRNA in osteogenic/stromal cells (Yamagishi et al. 2001). Quercetin (Notoya et al. 2004) and curcumin (Notoya et al. 2006) have been reported to inhibit cultured osteoblast metabolism. In addition, curcumin (Bharti et al. 2004) and quercetin (Woo et al. 2004) have been found to inhibit osteoclastogenesis. Kamon et al. (2010) reported that the green tea polyphenol epigallocatechin gallate inhibited the differentiation of murine osteoblastic MC3T3-E1 cells and the formation of osteoclasts. Recently, we showed that the olive polyphenols oleuropein and hydroxytyrosol accelerate osteoblast differentiation and mineralization, inhibit osteoclast formation in culture, and attenuate bone loss in OVX mice (Hagiwara et al. 2011). Thus, polyphenols regulate bone metabolism in culture via osteoblasts and osteoclasts.

In this study, we attempted to clarify the potential effects of apigenin on bone metabolism. We found that apigenin inhibited osteoblast differentiation markers such as type I collagen production, alkaline phosphatase activity, and calcium deposition by MC3T3-E1 

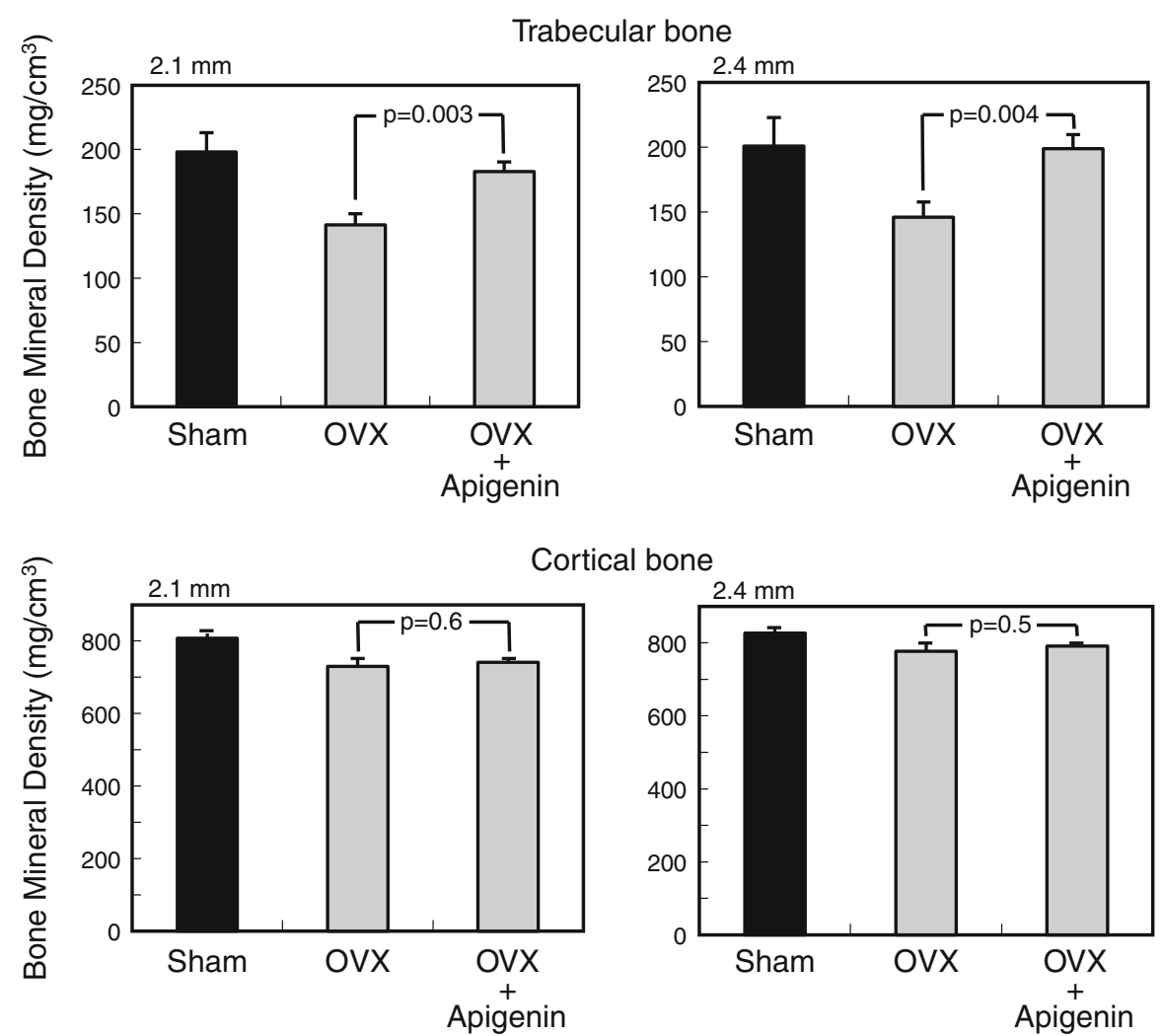

Fig. 5 Effects of apigenin on the bone mineral density of the femurs of OVX mice. BALB/c female mice (6-week old) underwent a sham operation $(n=5)$ or were surgically ovariectomized (OVX; $\mathrm{n}=10$ ) under anesthesia. Mice were assigned to three groups ( $\mathrm{n}=5$ for each): Sham, sham-operated controls; OVX controls; OVX + Api, OVX administered intraperitoneally with apigenin $\left(10 \mathrm{mg} \mathrm{kg}^{-1}\right.$ body weight $)$ at

osteoblasts. Furthermore, apigenin attenuated the formation of multinucleated osteoclasts in culture. It has also been reported that apigenin inhibits osteoclastogenesis and osteoclast function (Bandyopadhyay et al. 2006). These findings indicate that apigenin has inhibitory effects on both osteoblastogenesis and osteoclastogenesis in vitro. Therefore, to confirm whether apigenin contributes to reduction in the risk of osteoporosis, we investigated the preventive effects of apigenin on bone formation in vivo. Our results showed that apigenin markedly reduced bone loss in trabecular bone but had no effect on cortical bone loss in OVX mice. Experiments involving OVX female Sprague-Dawley rats (Park et al. 2008) have shown that apigenin prevents trabecular bone loss at a concentration of $10 \mathrm{mg} \mathrm{kg}^{-1}$ body weight. Thus,

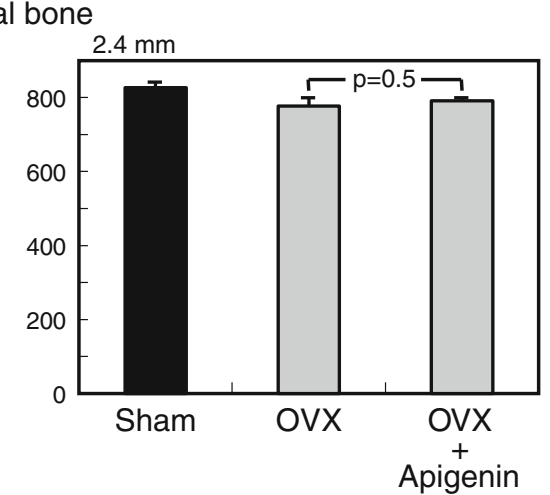

3-day intervals. After the 28-day experimental period, the left and right femurs were surgically collected from anaesthetized mice. Bone mineral density of the femurs (trabecular bone and cortical bone) was assessed using an X-ray CT System (LA Theata LCT-100; Aloka). It was monitored at $0.3 \mathrm{~mm}$ intervals, and the values at $2.1 \mathrm{~mm}$ and $2.4 \mathrm{~mm}$ from the femur epiphysis are shown in the figures

apigenin has been shown to reduce loss of bone mineral density in the trabecular bone in mice and rats.

It is well known that polyphenols have antioxidant properties (Rice-Evans et al. 1995). Recent reports have suggested that reactive oxygen species (ROS) play an important role in the regulation of cell proliferation, differentiation and metabolism. In particular, ROS inhibit the formation of bone by osteoblastic cells (Hosoya et al. 1998; Lee et al. 2006; Mody et al. 2001). Oxidative stress resulting in increased levels of intracellular ROS has been reported to suppress bone metabolism. Arai et al. (2007) reported that mineralization by MC3T3-E1 cells was reduced by half after a single exposure to $\mathrm{H}_{2} \mathrm{O}_{2}$ within the nontoxic concentration range. In addition, there have been some reports that $\mathrm{H}_{2} \mathrm{O}_{2}$ suppresses differentiation 
markers such as alkaline phosphatase activity, type I collagen gene expression, and the mineralization of osteoblastic cells (Hosoya et al. 1998; Lee et al. 2006; Mody et al. 2001). We had previously reported that apigenin does not demonstrate antioxidant effects in MC3T3-E1 cells (Hagiwara et al. 2011). Therefore, the inhibitory effects of apigenin on osteoblasts and osteoclasts in this study do not depend on a reduction in $\mathrm{H}_{2} \mathrm{O}_{2}$ levels.

In conclusion, the olive and parsley polyphenol apigenin markedly inhibited the formation of multinucleated osteoclasts in culture and prevented bone loss in an experimental model of osteoporosis (OVX mice). These findings suggest that apigenin may provide insights into the development of tools useful for the prevention and treatment of osteoporosis. Further investigation is required to clarify the detailed molecular mechanisms underlying the activity of apigenin in bone.

Acknowledgments This work was supported by Grants-inAid for Scientific Research from the Ministry of Education, Science, Sports and Culture of Japan. We would like to thank Mrs. K. Nakata for assistance with cell culture and Mrs. K. Takada for mouse maintenance.

Open Access This article is distributed under the terms of the Creative Commons Attribution License which permits any use, distribution, and reproduction in any medium, provided the original author(s) and the source are credited.

\section{References}

Arai M, Shibata Y, Pugdee K, Abiko Y, Ogata Y (2007) Effects of reactive oxygen species (ROS) on antioxidant system and osteoblastic differentiation in MC3T3-E1 cells. IUBMB Life 59:27-33

Bandyopadhyay S, Lion J-M, Mentaverri R, Ricupero DA, Kamel S, Romero JR, Chattopadhyay N (2006) Attenuation of osteoclastogenesis and osteoclast function by apigenin. Biochem Pharmacol 72:184-197

Bharti AC, Takada Y, Aggarwal BB (2004) Curcumin (diferuloymethane) inhibits receptor activator of NF- $\kappa B$ ligandinduced NF- $\mathrm{\kappa B}$ activation in osteoclast precursors and suppresses osteoclastogenesis. J Immunol 172:5940-5947

Bredford JN, Graves SE, Smoothy CA (1993) Formation of mineralized nodules by bone derived cells in vitro: a model of bone formation? Am J Med Genet 45:163-178

Budhraja A, Gao N, Zhang Z, Son YO, Cheng S, Wang X, Ding S, Hitron A, Chen G, Luo J, Shi X (2012) Apigenin induces apoptosis in human leukemia cells and exhibits anti-leukemic activity in vivo. Mol Cancer Ther 11:132-142

Hagiwara H, Inoue A, Yamaguchi A, Yokose S, Furuya M, Tanaka S, Hirose S (1996) cGMP produced in response to
ANP and CNP regulates proliferation and differentiation of osteoblastic cells. Am J Physiol 270:C1311-C1318

Hagiwara K, Goto T, Araki M, Miyazaki H, Hagiwara H (2011) Olive polyphenol hydroxytyrosol prevents bone loss. Eur J Pharmacol 662:78-84

Hosoya S, Suzuki H, Yamamoto M, Kobayashi K, Abiko Y (1998) Alkaline phosphatase and type I collagen gene expressions were reduced by hydroxyl radical-treated fibronectin substratum. Mol Genet Metab 65:31-34

Kamon M, Zhao R, Sakamoto K (2010) Green tea polyphenol (-)-epigallocatechin gallate suppressed the differentiation of murine osteoblastic MC3T3-E1 cells. Cell Biol Int 34: 109-116

Lee SF, Lin JK (1997) Inhibitory effects of phytopolyphenols on TPA-induced transformation, PKC activation, and c-jun expression in mouse fibroblast cells. Nutr Cancer 28: 177-183

Lee DH, Lim BS, Lee YK, Yang HC (2006) Effects of hydrogen peroxide $\left(\mathrm{H}_{2} \mathrm{O}_{2}\right)$ on alkaline phosphatase activity and matrix mineralization of odontoblast and osteoblast cell lines. Cell Biol Toxicol 22:39-46

Liang YC, Huang YT, Tsai SH, Lin-Shiau SY, Chen CF, Lin JK (1999) Suppression of inducible cyclooxygenase and inducible nitric oxide synthase by apigenin and related flavonoids in mouse macrophages. Carcinogenesis 20: 1945-1952

Liu F, Malaval L, Gupta AK, Aubin JE (1994) Simultaneous detection of multiple bone-related mRNAs and protein expression during osteoblast differentiation: polymerase chain reaction and immunocytochemical studies at the single cell level. Dev Biol 166:220-234

Mody N, Parhami F, Sarafian TA, Demer LL (2001) Oxidative stress modulates osteoblastic differentiation of vascular and bone cells. Free Radic Biol Med 31:509-519

Notoya M, Tsukamoto Y, Nishimura H, Woo J-T, Nagai K, Lee I-S, Hagiwara H (2004) Quercetin, a flavonoid, inhibits the proliferation, differentiation, and mineralization of osteoblasts in vitro. Eur J Pharmacol 485:89-96

Notoya M, Nishimura H, Woo J-T, Nagai K, Ishihara Y, Hagiwara $H$ (2006) Curcumin inhibits the proliferation and mineralization of cultured osteoblasts. Eur J Pharmacol 534:55-62

Notoya M, Arai R, Katafuchi T, Minamino N, Hagiwara H (2007) A novel member of the calcitonin gene-related peptide family, calcitonin receptor-stimulating peptide, inhibits the formation and activity of osteoclasts. Eur $\mathbf{J}$ Pharmacol 560:234-239

Park JA, Ha SK, Kang TH, Oh MS, Cho MH, Lee SY, Park J-H, Kim SY (2008) Protective effect of apigenin on ovariectomy-induced bone loss in rats. Life Sci 82:1217-1223

Patel D, Shukla S, Gupta S (2007) Apigenin and cancer chemoprevention: progress, potential and promise. Int J Oncol 30:233-245

Rice-Evans CA, Miller NJ, Bolwell PG, Bramley PM, Pridham JB (1995) The relative antioxidant activities of plantderived polyphenolic flavonoids. Free Radic Res 22: 375-383

Riggs BL (1987) Pathogenesis of osteoporosis. Am J Obstet Gynecol 156:1342-1346

Shukla S, Gupta S (2007) Apigenin-induced cell cycle arrest is mediated by modulation of MAPK, PI3 K-Akt, and loss of 
cyclin D1 associated retinoblastoma dephosphorylation in human prostate cancer cells. Cell Cycle 6:1102-1114

Shukla S, Gupta S (2010) Apigenin: a promising molecule for cancer prevention. Pharm Res 27:962-978

Stein GS, Lian JB, Owen TA (1990) Relationship of cell growth to the regulation of tissue-specific gene expression during osteoblast differentiation. FASEB J 4:3111-3123

Tullberg-Reinert H, Jundt G (1999) In situ measurement of collagen synthesis by human bone cells with a Sirius Redbased colorimetric microassay: effects of transforming growth factor $\beta 2$ and ascorbic acid 2-phosphate. Histochem Cell Biol 112:271-276

Udagawa N, Takahashi N, Akatsu T, Tanaka H, Sasaki T, Nishihara T, Koga T, Martin TJ, Suda T (1990) Origin of osteoclasts: mature monocytes and macrophages are capable of differentiating into osteoclasts under a suitable microenvironment prepared by bone marrow-derived stromal cells. Proc Natl Acad Sci USA 87:7260-7264
Wei H, Tye L, Bresnick E, Birt DF (1990) Inhibitory effect of apigenin, a plant flavonoid, on epidermal ornithine decarboxylase and skin tumor promotion in mice. Cancer Res 50:499-502

Woo J-T, Nakagawa H, Notoya M, Yonezawa T, Udagawa N, Lee I-S, Ohnishi M, Hagiwara H, Nagai K (2004) Quercetin suppresses bone resorption by inhibiting the differentiation and activation of osteoclasts. Biol Pharm Bull 27:504-509

Yamagishi T, Otsuka E, Hagiwara H (2001) Reciprocal control of expression of mRNAs for osteoclast differentiation factor and OPG in osteogenic stromal cells by genistein: evidence for the involvement of topoisomerase II in osteoclastogenesis. Endocrinology 142:3632-3637

Zhu Y, Mao Y, Chen H, Lin Y, Hu Z, Wu J, Xu X, Xu X, Qin J, Xie L (2013) Apigenin promotes apoptosis, inhibits invasion and induces cell cycle arrest of T24 human bladder cancer cells. Cancer Cell Int 13:54. doi:10.1186/1475-2867-13-54 